\title{
A polymerase chain reaction enzyme immunoassay for diagnosing infection caused by Aspergillus fumigatus
}

Nasser Golbang, James P Burnie, Ruth C Matthews

\begin{abstract}
Aim-To develop a polymerase chain reaction enzyme immunoassay (PCREIA) to measure levels of circulating aspergillus DNA in invasive aspergillosis caused by Aspergillus fumigatus.

Methods-The PCR reaction was based on primers from the $18 \mathrm{~s}$ rRNA gene. Binding of the product to a streptavidin coated microtitration plate was mediated by a biotinylated capture probe. The product was digoxigenylated during PCR and this was the tag to which antibody was bound in the subsequent EIA.

Results-The optical density (OD) endpoint was $<0.1$ in 10 sera from neutropenic patients with no evidence of invasive aspergillosis, and in 10 sera from nonneutropenic patients with bacterial pneumonia (group 1). The OD from five of 12 patients with allergic bronchopulmonary aspergillosis (ABPA) (group 2), three with an aspergilloma (group 3), and five with possible invasive aspergillosis (group 4) was $\geqslant 0.1$. In 63 sera from 33 cases of proven invasive aspergillosis (group 5) an $O D \geqslant 0.1$ was achieved in 48 sera from 30 patients. The maximum OD was 0.510 . The level fell in survivors and gradually rose in fatal cases.

Conclusions-This assay validated the concept of diagnosing invasive aspergillosis by measuring levels of circulating fungal DNA in serum.

(f Clin Pathol 1999;52:419-423)
\end{abstract}

Keywords: aspergillosis; polymerase chain reaction

Aspergillus fumigatus is becoming increasingly important as a cause of invasive aspergillosis, allergic bronchopulmonary aspergillosis (ABPA), and aspergilloma. ${ }^{1}$ In invasive aspergillosis the high mortality, ${ }^{2}$ the perception that obtaining a diagnosis by routine culture is difficult, and the cost of the newer formulations of amphotericin $\mathrm{B}^{3}$ have led to a need for better diagnostic tests. A further result of this increased cost has been a desire to move from antifungal treatment for all at risk patients to the selective use of these drugs in patients with proven infection. ${ }^{4}$ The gold standard for antemortem diagnosis is histological and culture evidence from either an open or a transbronchial lung biopsy. This is hazardous, expensive to perform, and some patients may be too ill. Lesions typical of invasive aspergillosis have been described by computed tomogra- phy but this may be difficult to perform owing to the limited availability of the equipment. ${ }^{5}$

Invasive aspergillosis is primarily a lung infection so the obvious sample for establishing the diagnosis is sputum culture. This has been reported to be insensitive, with a positivity rate in immunocompromised patients varying from $15 \%$ to $69 \% .{ }^{6}$ Diagnosis by antibody detection has been disappointing as many of those infected are incapable of mounting a response. ${ }^{5}$ Survival has been correlated with antibody to a band at $88 \mathrm{kDa}^{7}$ and the immunodominance of a band of molecular weight ranging from $88-93 \mathrm{kDa}$ has been repeatedly reported in patients with invasive aspergillosis, ABPA, and aspergilloma..$^{7-11}$

Antigen detection has concentrated on the detection of galactomannan by enzyme linked immunosorbent assay and the Pastorex $A s-$ pergillus test (Sanofi Diagnostic Pasteur) which employs a rat $\operatorname{IgM}$ monoclonal antibody EB-A2 in an agglutination based test. ${ }^{12}{ }^{13}$ This latter test has been criticised for a lack of sensitivity, false positives, and a tendency for being positive late in the disease when invasive aspergillosis is refractive to treatment. ${ }^{14}{ }^{15}$

Recently the polymerase chain reaction (PCR) has been applied to the diagnosis of systemic fungal infections. In invasive aspergillosis, targets have either been limited copy genes, for example the $18 \mathrm{kDa}$ immunoglobulin $\mathrm{E}$ binding protein ${ }^{16}$ and alkaline protease, ${ }^{17}$ or multiple copy genes such as the $26 \mathrm{~S}$ intergenic spacer gene, ${ }^{18}$ the $18 \mathrm{~S}$ rRNA genes, ${ }^{19}$ mitochondrial DNA, ${ }^{20}$ or panfungal targets such as the small subunit rRNA gene. ${ }^{21}$ Specimens obtained at bronchoscopy have been tried but the sensitivity can be low and false positives have occurred. ${ }^{22-24}$ Recently an aspergillus specific nested PCR has been described which successfully detected DNA specific for $A s-$ pergillus spp in the sera of experimentally infected mice and patients with invasive aspergillosis. ${ }^{19}$ In this paper, we present a modification of this assay by removing the need for a nested reaction and converting it into a semiquantitative test. This type of assay has been of value in the diagnosis of invasive candidiasis where the level of circulating fungal DNA correlated with the response to treatment and provided evidence that it might form a surrogate marker of active disease. ${ }^{25}$

The format involved binding the amplified product with a biotinylated capture probe to a streptavidin coated microtitration plate and addition of the digoxigenin label during PCR. This was developed as an enzyme immunoassay 
(EIA) with an optical density (OD) endpoint. Sensitivity was determined by a titration with purified aspergillus DNA.

We examined sera from patients with no evidence of clinical disease caused by $A$ fumigatus, with an aspergilloma, with ABPA, and with possible (pyrexia, abnormal chest $x$ ray, response to antifungal treatment) and proven (culture and histological evidence at bronchoscopy or necropsy) invasive aspergillosis. Each serum was tested for the presence of fungal DNA by PCR and, for comparison, for antigen by reverse passive latex agglutination (RPLA) ${ }^{26}$ and for antibody by immunoblot. ${ }^{7}$

\section{Methods}

All the patients, except for some in group 5, where multiple sera were available, were represented by a single serum stored at $-80^{\circ} \mathrm{C}$ for a period of up to five years.

- Group 1-Sera were obtained from pyrexial neutropenic patients with no evidence of invasive aspergillosis $(\mathrm{n}=10)$ and nonneutropenic patients with bacterial pneumonia $(\mathrm{n}=10)$.

- Group 2-ABPA (n=12), with recurrent pulmonary infiltrates, asthma, blood eosinophilia, a positive serum precipitin test, and sputum culture for $A$ fumigatus.

- Group 3-Aspergilloma $(\mathrm{n}=3)$, with chest $x$ ray changes showing a discrete lesion with a halo and a positive culture for $A$ fumigatus obtained either repeatedly from sputum or by bronchoscopy.

- Group 4-Possible invasive aspergillosis from pyrexial neutropenic patients when they had an abnormal chest $x$ ray and were recovering on antifungal treatment $(n=5)$. All had antibody on immunoblot including a band at 88 $\mathrm{kDa}$ as an entry criterion.

- Group 5-Proven invasive aspergillosis as diagnosed by positive culture and histological evidence obtained at either bronchoscopy (cases 1-5) or necropsy (cases 6-33) (table 1). During life, cases 6-11 had a normal chest $x$ ray and a negative sputum culture, cases $12-16$ an abnormal chest $x$ ray and a negative sputum culture, and cases 17-33 an abnormal chest $x$ ray and a positive sputum culture for A fumigatus. All patients had acute myeloid leukaemia except case 3 who had chronic granulomatous disease, case 6 aplastic anaemia, and case 27 chronic obstructive airways disease on high dose steroids (table 1). An additional CSF sample, which was from a patient with histological evidence of cerebral aspergillosis, was available from case 30 .

In the patients where only a single serum was available this was taken within a maximum of two days before death. In the fatal cases where multiple sera were examined, these were at weekly intervals until the final serum, which was taken within two days of death. In the survivors (cases 1-5) the first serum coincided with the patient being pyrexial, having an abnormal chest $x$ ray, and performance of the bronchoscopy. Subsequent sera were obtained
Table 1 Details of the 33 patients in group 5 with proven invasive aspergillosis

\begin{tabular}{|c|c|c|c|c|c|}
\hline $\begin{array}{l}\text { Patient } \\
\text { No }\end{array}$ & $\begin{array}{l}\text { No } \\
\text { of } \\
\text { sera }\end{array}$ & $\begin{array}{l}\text { No of sera } \\
\text { with } \\
\text { antibody }\end{array}$ & $\begin{array}{l}\text { No of sera } \\
\text { with RPLA } \\
\text { titre } \geqslant 1.4\end{array}$ & $\begin{array}{l}\text { Maximum } \\
\text { OD by } \\
P C R-E I A\end{array}$ & $\begin{array}{l}\text { No of sera } \\
\text { with } \\
O D \geqslant 0.1\end{array}$ \\
\hline 1 & 3 & 3 & 0 & 0.190 & 2 \\
\hline 2 & 3 & 3 & 1 & 0.190 & 3 \\
\hline 3 & 3 & 2 & 1 & 0.240 & 2 \\
\hline 4 & 2 & 2 & 1 & 0.150 & 1 \\
\hline 5 & 2 & 2 & 1 & 0.390 & 1 \\
\hline 6 & 1 & 1 & 1 & 0.100 & 1 \\
\hline 7 & 1 & 0 & 1 & 0.100 & 1 \\
\hline 8 & 5 & 0 & 1 & 0.510 & 3 \\
\hline 9 & 1 & 0 & 0 & 0.160 & 1 \\
\hline 10 & 1 & 0 & 1 & 0.230 & 1 \\
\hline 11 & 2 & 0 & 0 & 0.210 & 1 \\
\hline 12 & 5 & 0 & 4 & 0.350 & 4 \\
\hline 13 & 2 & 0 & 1 & 0.140 & 2 \\
\hline 14 & 1 & 0 & 0 & 0.072 & 0 \\
\hline 15 & 1 & 0 & 1 & 0.210 & 1 \\
\hline 16 & 2 & 0 & 1 & 0.240 & 2 \\
\hline 17 & 6 & 5 & 3 & 0.260 & 6 \\
\hline 18 & 2 & 0 & 1 & 0.150 & 2 \\
\hline 19 & 2 & 0 & 1 & 0.270 & 2 \\
\hline 20 & 1 & 1 & 0 & 0.070 & 0 \\
\hline 21 & 1 & 1 & 1 & 0.120 & 1 \\
\hline 22 & 1 & 0 & 0 & 0.060 & 0 \\
\hline 23 & 1 & 1 & 1 & 0.120 & 1 \\
\hline 24 & 1 & 0 & 1 & 0.130 & 1 \\
\hline 25 & 1 & 0 & 1 & 0.140 & 1 \\
\hline 26 & 1 & 0 & 0 & 0.220 & 1 \\
\hline 27 & 1 & 0 & 1 & 0.200 & 1 \\
\hline 28 & 1 & 1 & 0 & 0.210 & 1 \\
\hline 29 & 2 & 0 & 1 & 0.180 & 2 \\
\hline 30 & 2 & 0 & 0 & 0.190 & 1 \\
\hline 31 & 1 & 0 & 1 & 0.200 & 1 \\
\hline 32 & 2 & 0 & 1 & 0.205 & 2 \\
\hline 33 & 2 & 0 & 0 & 0.215 & 1 \\
\hline
\end{tabular}

EIA, enzyme immunoassay; OD, optical density; PCR, polymerase chain reaction; RPLA reverse passive latex agglutination.

at 7 (cases 1 and 3), 28 (all cases), and 56 days (case 2).

AGGLUTINATION TESTS

The RPLA assay has been described elsewhere. ${ }^{26}$ The titres of positive sera were determined by serial dilution of sera in glycine buffered saline ( $\mathrm{pH} 8.4$ )

IMMUNOBLOTTING

The source of antigen was $A$ fumigatus NCPF 2109 and the analysis performed on a $10 \%$ polyacrylamide gel. Immunoblots were defined as positive for antibody when antibody was seen to have one or more bands including one at $88 \mathrm{kDa}^{7}$

POLYMERASE CHAIN REACTION

For specimen preparation, ${ }^{19} 100 \mu \mathrm{l}$ of serum were added to $100 \mu \mathrm{l}$ of lysis buffer $(20 \mathrm{mM}$ Tris $\mathrm{HCl}$ (pH 8.3), $100 \mathrm{mM} \mathrm{KCl,} 5 \mathrm{mM} \mathrm{Mg}$ $\mathrm{Cl}_{2}, 0.9 \%$ Tween 20 solution, $0.2 \mathrm{mg}$ of gelatin per $\mathrm{ml}$ and $0.6 \mu \mathrm{l}$ of $20 \mathrm{mg} / \mu \mathrm{l}$ of proteinase $\mathrm{K}$ ) was added. The mixture was incubated for 60 minutes at $55^{\circ} \mathrm{C}$ and for 10 minutes at $95^{\circ} \mathrm{C}$. Following centrifugation (12000 g for $10 \mathrm{~min}$ utes at $4^{\circ} \mathrm{C}$ ), $5 \mu \mathrm{l}$ was used for PCR.

A negative control of $5 \mu \mathrm{l}$ of redistilled water was used in each batch of assays. The positive control was $5 \mu \mathrm{l}$ of redistilled water containing $0.05 \mathrm{ng} / \mu \mathrm{l}$ of purified $A$ fumigatus NCPF 2109 DNA produced as described previously. ${ }^{27}$ To establish test sensitivity a titration of the reaction with this DNA from 0 to $50 \mathrm{ng} / \mu \mathrm{l}$ of serum was performed on three occasions.

Oligonucleotides were synthesised with a DNA synthesiser (Applied Biosystems). The 
initial primers for amplification were Asp 5 (5' GATAAC GAACGA GAC CTC GG $3^{\prime}$ ) and Asp 8 (5' TGC CAA CTC CCC TGA GCC AG 3'), which amplified a 384 bp sequence. The sequence of the specific capture biotinylated probe was Asp.p 5' ATG GAA GTG CGC GGC AAT AAC 3'.[19 ]

The final composition of the $50 \mu 1$ PCR mixture was $5 \mu \mathrm{l}$ of $10 \times$ PCR buffer $(100 \mathrm{mM}$ Tris $\mathrm{HCl}, 15 \mathrm{mM} \mathrm{Mg} \mathrm{Cl}, 500 \mathrm{mM} \mathrm{KCl}, \mathrm{pH}$ 8.3), $4 \mu \mathrm{l}$ of PCR digoxigenin labelling mix, $1 \mu \mathrm{l}$ (50 pmol) of each primer, $2 \mathrm{U}$ of Taq polymerase, $33.6 \mu \mathrm{l}$ of double distilled water, and $5 \mu \mathrm{l}$ of the extracted specimen or the positive or negative control. The mixture was placed in a PerkinElmer DNA thermal cycler (Roche 96) and incubated at $94^{\circ} \mathrm{C}$ for five minutes. Polymerase chain reaction conditions were as follows: one minute at $94^{\circ} \mathrm{C}$, one minute at $50^{\circ} \mathrm{C}$, and three minutes at $72^{\circ} \mathrm{C}$ for 40 cycles, and seven minutes at $72^{\circ} \mathrm{C}$. After amplification, $10 \mu \mathrm{l}$ of the amplified product was run on $1 \%$ agarose gel in the presence of ethidium bromide $(0.5 \mu \mathrm{l} / \mathrm{ml})$ for one to two hours at $55 \mathrm{~V}$ and visualised by ultraviolet illumination.

ENZYME IMMUNOASSAY

To $50 \mu$ of the PCR product was added $40 \mu$ of the denaturation solution; this mixture was incubated for 10 minutes at room temperature. Hybridisation buffer containing $7.5 \mathrm{pmol} / \mathrm{mol}$ biotinylated capture probe was added to a total volume of $500 \mu \mathrm{l}$. After vortexing, $200 \mu \mathrm{l}$ were pipetted into each of two wells on a streptavidin coated microtitre plate. The plate was incubated for three hours at $45 \circ \mathrm{C}$ with shaking. After washing with phosphate buffered saline containing $0.5 \%$ Tween $20,200 \mu \mathrm{l}$ of peroxidase conjugated antidigoxigenin Fab fragment diluted 1:100 in hybridisation buffer were added to each well and incubated at $37^{\circ} \mathrm{C}$ for 30 minutes. Plates were washed three times with buffer. Each well then received $200 \mu \mathrm{l}$ of ABTS (2,2' azino-bis 3 ethyl benz-thiazoline 6-sulphonic acid) substrate solution and was incubated at $37^{\circ} \mathrm{C}$ with shaking for 30 minutes in darkness. The A405 of each well was determined with a microtitration plate reader (UV Max; Molecular Devices) and from the average of two wells representing each sample the absorbance of a reagent blank containing $10 \mu \mathrm{l}$ of distilled water was subtracted. All enzymes, buffers, and antibodies were purchased from Boehringer-Mannheim and the reactions performed according to their protocols.

\section{Results}

The titration of the purified $A$ fumigatus NCPF 2109 DNA gave a mean (SD) optical density of $0.081(0.009)$ at $0 \mathrm{ng} / \mu \mathrm{l}, 0.198(0.014)$ at 0.05 $\mathrm{ng} / \mu \mathrm{l}, 0.353(0.010)$ at $0.5 \mathrm{ng} / \mu \mathrm{l}, 0.603(0.024)$ at $5 \mathrm{ng} / \mu \mathrm{l}$, and $0.855(0.043)$ at $50 \mathrm{ng} / \mu \mathrm{l}$. A concentration of $0.05 \mathrm{ng} / \mathrm{ml}$ of purified fungal DNA was the positive control as it gave an OD of approximately 0.2. All the sera which produced a positive PCR-EIA were positive by ethidium bromide stained agarose gel electrophoresis.

The sera from group 1 were antigen and antibody negative. The PCR-EIA ODs varied from 0.02 to 0.09 . No control serum had an $\mathrm{OD}$ of $\geqslant 0.1$, so this level was used for defining a patient as at risk of having invasive disease. It was also the minimum point detectable in the assay with purified fungal DNA, where it was equivalent to $0.02 \mathrm{ng} / \mu \mathrm{l}$.

The sera from group 2 were negative by RPLA and positive for antibody. The PCR-EIA OD value varied from 0.07 to 0.218 , with a value greater than 0.1 in five patients $(0.120$, $0.140,0.160,0.203$, and 0.218 ).

The sera from group 3 were antigen negative and antibody positive. The PCR-EIA OD value varied from 0.170 to 0.260 .

The sera from group 4 had detectable antibody as an entry criterion. Two of the sera produced non-specific agglutination in the RPLA test, one a titre of 1 in 2 , and the remaining two were antigen negative. The PCR-EIA OD in these cases of possible invasive aspergillosis varied from 0.120 to 0.215 .

Group 5 were proven cases of invasive aspergillosis, with 63 sera examined from 33 cases (table 1). Antibody was positive in 23 sera from 11 cases including all the survivors in group 5 and case 20 which was negative for both antigen detection and PCR-EIA. Antigen at a titre of 1 in 4 or greater was positive in 29 sera from 24 cases. No case was solely antigen positive, while cases 1 and 28 were antigen negative and positive for antibody and by PCR-EIA. PCR-EIA had the highest sensitivity, being positive in 48 sera from 30 patients. The maximum OD was 0.510 and thus the range of concentration of detectable circulating fungal DNA was 0.02 (equivalent to an $\mathrm{OD}$ of $0.1)$ to $1.7 \mathrm{ng} / \mu \mathrm{l}$. This was derived from a semilogarithmic plot of the concentration of purified $A$ fumigatus NCPF 2109 DNA against the resultant mean optical density in the titration used to define the positive control.

In case 28 the CSF sample had an OD of 0.210 which was equivalent to approximately $0.06 \mathrm{ng} / \mu \mathrm{l}$ of purified fungal DNA.

In cases $1-5$ the initial sera were antibody and PCR-EIA positive. Sequential sampling showed that after seven days of antifungal treatment there were persistently positive results from cases $1(0.180)$ and 3 (0.150). Sampling at 28 days gave negative results in cases $1,3,4$, and $5(0.07,0.07,0.08$, and 0.09 , respectively). In case 2 the value at 28 days was 0.170 and by 56 days it had fallen to 0.08 .

In the patients who died and where multiple samples were available, the average value of the earliest sera was 0.115 (equivalent to 0.25 $\mathrm{ng} / \mu \mathrm{l})$ while the latest sera had an average value of 0.24 (equivalent to $0.8 \mathrm{ng} / \mu \mathrm{l}$ ). The time interval between these samples ranged from 30 to 84 days. The earliest serum had an OD of 0.1 or greater in seven cases and in the final sera this was achieved in all 12 cases. In contrast, a positive antigen was achieved in none of the earliest serum and in only nine of the terminal sera.

There was no correlation between either an abnormal chest $x$ ray or a positive sputum culture and a higher level of circulating fungal DNA in cases 6-33. The average OD derived 
from the sera with the maximum OD was 0.218 (cases 6-11), 0.202 (cases 12-16), and 0.173 (cases 17-33). The PCR negative cases $(14,20$, and 22) all had abnormal chest $x$ rays while paradoxically none of the cases with a normal chest $x$ ray and negative sputum failed to produce a positive PCR-EIA.

\section{Discussion}

The results show that PCR-EIA based on sequences derived from the $18 \mathrm{~S}$ rRNA gene of A fumigatus DNA could be used to quantify the level of circulating DNA in invasive aspergillosis. All the group 1 sera with no evidence of aspergillus colonisation or infection were negative. Five patients with ABPA and all three patients with an aspergilloma produced an OD greater than 0.1 . This suggested circulating aspergillus DNA in the absence of clinical invasive aspergillosis or a raised antigen titre. It is consistent with a model where the fungus is chronically degraded by autolysis and macrophages leading to DNA release measurable by PCR, antigen release undetectable by insensitive RPLA, and antibody stimulation shown on immunoblot. PCR positive results have also been obtained directly from surgically removed aspergillomas, ${ }^{28}$ from serum from a patient with an aspergilloma, ${ }^{29}$ and from serum of a case of aspergillus endocarditis. ${ }^{30}$

Studies in invasive aspergillosis have concentrated on bronchoalveolar lavage and bronchial washings, ${ }^{17} 182022-2431$ but there has been a persistent problem with false positives. Spreadbury et al reported two PCR positive results from seven immunocompetent patients, ${ }^{18}$ Tang et al reported five from 28 immunocompetent patients, ${ }^{17}$ Melchers et al three from eight neutropenic patients, ${ }^{31}$ and Bretagne et al 12 from 49 patients who did not develop invasive aspergillosis. ${ }^{22}$ This problem was independent of the sequence of the target and may be caused by colonisation of the patients' respiratory tract or by contamination during processing. Conversion of the assay to a semiquantitative format could resolve this, ${ }^{20}$ as reaching a particular OD might distinguish invasive disease. An artificially low OD might occur where there was a focal lesion as the amount of aspergillus DNA present would be dependent, in part, on which lobe was washed. The DNA level in a distant specimen such as blood or urine might more accurately reflect the degree of lung invasion. The current assay validates this concept. It could be improved further by including an internal control to detect the presence of non-specific polymerase inhibitors and to control the quality of the extracted DNA. ${ }^{20} 32$

The sensitivity achieved by nested PCR with sera from infected mice was $71 \%$, and in 20 patients with invasive aspergillosis it was $70 \% .{ }^{19}$ The same methods of sample preparation were applied here with identical initial primers. The change to the current format reduced the chance of contamination by avoiding a double PCR and still achieved a sensitivity of $94 \%$. Einsele et $a l^{32}$ with a zymolase digestion step followed by an alkaline heat treatment detecting the same aspergillus gene, demonstrated circulating aspergillus DNA in all 13 patients with invasive aspergillosis. This extraction protocol was more complex and the assay did not attempt to be semiquantitative.

The maximum level of aspergillus DNA detected was equivalent to $1.7 \mathrm{ng} / \mu \mathrm{l}$ of genomic DNA and the lowest detection limit was 0.02 $\mathrm{ng} / \mu \mathrm{l}$. This is less sensitive than the quantities of genomic DNA detected on ethidium bromide staining of gels ${ }^{16}{ }^{18}$ and the fg quantities detected following Southern hybridisation ${ }^{17} 183132$ or nested $^{19}$ or competitive PCR. ${ }^{22}$ Einsele et al stated that $50 \mathrm{fg}$ of DNA was equivalent to one colony forming unit of A fumigatus per $\mathrm{ml}$ (cfu/ml) of blood. ${ }^{32}$ The current assay required $100 \mu \mathrm{l}$ of serum and needed the equivalent of 2 ng of pure genomic DNA to be positive. Assuming a linear relation between each cfu and the quantity of DNA extracted, this would approximate to the DNA extractable from $4 \times 10^{4} \mathrm{cfu}$. Contamination with small numbers of airborne spores should thus not lead to a false positive. This was borne out by the results from the group 1 sera and is an advantage of a less sensitive assay.

The PCR-EIA was more sensitive than antigen detection by RPLA, both in terms of the total number of positive sera and the timing of the first positive test. This lack of sensitivity has frequently been reported ${ }^{12-15} 263^{33-35}$ and is complicated by a loss of sensitivity when samples are stored at $-20^{\circ} \mathrm{C}$ for more than six months. ${ }^{34}$ It may be compensated for by examining serial urine samples ${ }^{35}$ or by converting the test into an enzyme immunoassay. ${ }^{12}{ }^{13}{ }^{36-38} \mathrm{~A}$ false positive rate of up to $12 \%$ has been reported with serum and bronchoalveolar lavage fluids. ${ }^{23}{ }^{37}$ Clinical outcome has been correlated with the appearance or disappearance of antigen. ${ }^{26} 38$ This mirrors the present results where the level of DNA fell in survivors and rose in fatal cases.

The detection of antibody was the most insensitive test. Paradoxically, it was the only positive marker in case 20 and a universal finding in survivors of invasive aspergillosis. It was not associated with false positive results which has been a problem when antibody has been measured by counter immunoelectrophoresis. ${ }^{33}$

CONCLUSIONS

We have demonstrated the ability of PCR-EIA to measure and semiquantify the levels of circulating aspergillus DNA in invasive aspergillosis. The value of this test and its impact on clinical care will need to be assessed prospectively, as it could be a marker for both initiating and controlling expensive antifungal treatment. Further developments might also include the development of assays dependent on real time quantitative PCR using fluorescent probes, as this would reduce assay time. ${ }^{39}$

The Government of Iran supported Naser Golbang and North West Regional Health Authority provided a grant.

1 Denning DW. Invasive aspergillosis. Clin Infect Dis 1998;26:781-803

2 Wald A, Leisenring W, van Burik JA, et al. Epidemiology of Aspergillus infections in a large cohort of patients undergoing bone marrow transplantation. F Infect Dis 1997;175: ing bone

3 White MH, Anaissie EJ, Kusne S, et al. Amphotericin B colloidal dispersion vs amphotericin $\mathrm{B}$ as therapy for invasive aspergillosis. Clin Infect Dis 1997;24:635-42. 
4 Andriole VT. Aspergillus infections: problems in diagnosis and treatment. Infect Agent Dis 1996;5:47-54

5 Denning DW, Evans EGV, Kibbler CC, et al Guidelines for the investigation of invasive fungal infections in haematological malignancy and solid organ transplantation. Eur $\mathcal{F}$ Clin Microbiol Infect Dis 1997;16:424-36.

6 Horvath JA, Drummer S. The use of respiratory-tract cultures in the diagnosis of invasive pulmonary aspergillosis. Am f Med 1996;100:171-8.

7 Burnie JP, Matthews RC. Heat shock protein 88 and Aspergillus infection: $\mathcal{F}$ Clin Microbiol 1991;29:2099-106.

8 Kobayashi H, Depeaupuis JP, Bouchara JP, et al. An 88-kilodalton antigen secreted by Aspergillus fumigatus. Infect Immun 1993;61:4767-71.

9 Lopez-Medrano R, Ovejero MC, Calera JA, et al. An immunodominant 90-kilodalton Aspergillus fumigatus antigen is
the subunit of a catalase. Infect Immun 1995;63:4774-80.

10 Lopez-Medrano R, Ovejero MC, Calera JA, et al. Immunoblotting patterns in the serodiagnosis of Aspergilloma: antibody response to the $90 \mathrm{kDa}$ Aspergillus fumigatus antigen. Eur f Clin Microbiol Infect Dis 1996;15:146-52.

11 Haynes KA, Tuinstra P, Hughes TA, et al. Purification and characterisation of a $93 \mathrm{kDa}$ Aspergillus fumigatus antigen characterisation of a $93 \mathrm{kDa}$ Aspergillus fumigatus antigen
with diagnostic potential. $₹$ Med Vet Mycol 1996;34:421-6.

12 Sulahian A, Tabouret M, Ribaud P, et al. Comparison of an 2 Sulahian A, Tabouret $\mathrm{M}$, Ribaud $\mathrm{P}$, et al. Comparison of an enzyme immunoassay and latex agglutination test for detection of galactomannan in the diagnosis of invasive
sis. Eur F Clin Microbiol Infect Dis 1996;15:139-45.

13 Verweij PE, Stynen D, Rijs AJMM, et al. Sandwich enzymelinked immunosorbent assay compared with Pastorex latex agglutination tests for diagnosing invasive aspergillosis in immunocompromised patients. F Clin Microbiol 1995;33: 1912-14

14 Kappe R, Schulze-Berge A. New cause for false-positives results with the Pastorex Aspergillus antigen latex agglutination test. F Clin Microbiol 1993;31:2489-90.

15 Verweij PE, Rijs AJMM, De Pauw BE, et al. Clinical evaluation and reproducibility of the Pastorex Aspergillus ation and reproducibility of the Pastorex Aspergillus antigen latex agglutination test for diagn

16 Reddy LV, Kumar A, Kurup VP. Specific amplification of Aspergillus fumigatus DNA by polymerase chain reaction. Mol Cell Probes 1993;7:121-6.

17 Tang CM, Holden DW, Aufauvre-Brown A, et al. The detection of Aspergillus spp. by the polymerase chain reaction and its evaluation in bronchoalveolar lavage fluid. $A m$ Rev Resp Dis 1993;148:1313-17.

18 Spreadbury C, Holden D, Aufauvre-Brown A, et al. Detection of Aspergillus fumigatus by polymerase chain reaction. f Clin Microbiol 1993;31:615-21.

19 Yamakami Y, Hashimoto A, Tokimatsu I, et al. PCR detection of DNA specific for Aspergillus species in serum of patients with invasive aspergillosis, f Clin Microbiol 1996;34:2464-8.

20 Jones ME, Fox AJ, Barnes AJ, et al. PCR-ELISA for the early diagnosis of invasive pulmonary aspergillus infection in neutropenic patients. F Clin Pathol 1998;51:652-6.

21 Van Burik J, Myerson D, Schreckhise RW, et al. Panfungal PCR assay for detection of fungal infection in human blood PCecimens. F Clin Microbiol 1998;36:1169-75.

22 Bretagne S, Costa JM, Marmorat-Khuong A, et al. Detection of Aspergillus species DNA in bronchoalveolar lavage samples by competitive PCR. f Clin Microbiol 1995; 33:1164-8.
23 Verweij PE, Latgé JP, Rijs AJMM, et al. Comparison of antigen detection and PCR assay using bronchoalveolar lavage fluid for diagnosing invasive pulmonary Aspergillosis in patients receiving treatment for hematological malignancies. F Clin Microbiol 1995;33:3150-3.

24 Bart-Delabesse E, Marmorat-Khuong A, Costa JM, et al. Detection of Aspergillus DNA in bronchoalveolar lavage fluid of AIDS patients by the polymerase chain reaction. Eur $\mathcal{F}$ Microbiol Infect Dis 1996;15:24-5.

25 Burnie JP, Golbang N, Matthews RC. Semiquantitative polymerase chain reaction enzyme immunoassay for diagnosis of disseminated candidiasis. Eur $\mathcal{F}$ Clin Microbiol Infect Dis 1997;16:346-50.

26 Burnie JP. Antigen detection in invasive aspergillosis. $f$ Immun Methods 1991;143:87-195.

27 Burnie JP, Coke A, Matthews RC. Restriction endonuclease analysis of Aspergillus fumigatus DNA. F Clin Pathol 1992; 45:324-7.

28 Urata T, Kobayashi M, Imamura J, et al. Polymerase chain reaction amplification of Asp $\mathrm{f} I$ and alkaline protease genes from fungus balls: clinical application in pulmonary aspergillosis. Intern Med 1997;36:19-27.

29 Hashimoto A, Yamakami Y, Mizunoe S, et al. Detection of Aspergillus species DNA in serum samples of the patients with non-invasive pulmonary aspergillosis. KansenshogakuZasshi 1997;71:255-9.

30 Kanda Y, Akiyama H, Onozawa Y, et al. Aspergillus endocarditis in a leukemia patient diagnosed by a PCR assay. Kansenshogaku-Zasshi 1997;71:269-72.

31 Melchers WJG, Verweij PE, van den Hurk P, et al. General primer-mediated PCR for detection of Aspergillus species. f Clin Microbiol 1994;32:1710-17.

32 Einsele H, Hebart H, Roller G, et al. Detection and identification of fungal pathogens in blood by using molecular probes. F Clin Microbiol 1997;35:1353-60.

33 Manso E, Montillo M, De Sio G, et al. Value of antigen and antibody detection in the serological diagnosis of invasive aspergillosis in patients with haematological malignancies. Eur f Clin Microbiol Infect Dis 1994;13:756-60.

34 Hopwood V, Johnson EM, Cornish JM, et al. Use of Pastorex Aspergillus antigen latex agglutination test for the diagnosis of invasive aspergillosis. F Clin Pathol 1995;48:21013.

35 Ansorg R, Heintschel von Heinegg E, Rath PM. Aspergillus antigenuria compared to antigenemia in bone marrow transplant recipients. Eur $\mathcal{f}$ Clin Microbiol Infect Dis 1994;13:582-9.

36 Haynes K, Rogers TR. Retrospective evaluation of latex agglutination tests for diagnosis of invasive aspergillosis in immunocompromised patients. Eur 7 Clin Microbiol Infect Dis 1994;13:670-4.

37 Bretagne S, Marmorat-Khuong A, Kuentz M, et al. Serum Aspergillus galactomannan antigen testing by sandwich ELISA: practical use in neutropenic patients. F Infect 1997; 35:7-15.

38 Rohrlich P, Sarfati J, Mariani P, et al. Prospective sandwich enzyme-linked immunosorbent assay for serum galactomannan: early predictive value and clinical use in invasive aspergillosis. F Pediatr Infect Dis 1996;15:232-7.

39 Heid CA, Stevens J, Livak KJ, et al. Real time quantitative PCR. Gen Res 1996;6:986-94. 